\title{
PENERAPAN GREEN ACCOUNTING TERHADAP KINERJA KEUANGAN
}

\author{
Bella Syafrina Qolbiatin Faizah \\ bellafaizaa@gmail.com \\ Universitas Negeri Surabaya \\ Jl. Lidah Wetan, Lidah Wetan, Kec. Lakarsantri, Kota Ssurabaya, Jawa Timur 60213
}

received: 10/6/2020; revised: 19/10/2020; approved: 28/10/2020

\begin{abstract}
The industrial revolution era resulted several of companies trying to produce products for human needs. These products produce waste where the waste can be one of the problems that occurs when the management building is damaged. This research aims to examine the effect of applying green accounting to financial performance. Green accounting focuses on environmental activities, green prooduct, and environmental performance using PROPER, while financial performance uses net profit margin. The sample selection using a purposive sampling technique that uses certain criteria about 24 companies in four periods. Data analysis techniques used multiple linear regression analysis. The results of this study indicate that green accounting has no effect on financial performance which is measured using a net profit margin.
\end{abstract}

Keywords: green accounting; environmental activity; green product; environmental performances; financial performances; net profit margin

\begin{abstract}
Abstrak
Era revolusi industri mengakibatkan sejumlah perusahaan berusaha menghasilkan produk untuk memenuhi kebutuhan manusia. Produk tersebut menghasilkan limbah di mana limbah tersebut dapat menjadi salah satu permasalahan lingkungan ketika perusahaan mengabaikan pengelolaan limbah yang dihasilkan. Penelitian ini bertujuan untuk menguji pengaruh penerapan green accounting terhadap kinerja keuangan. Green accounting berfokus pada aktivitas lingkungan, produk ramah lingkungan, dan kinerja lingkungan menggunakan PROPER, sedangkan kinerja keuangan menggunakan net profit margin. Pemilihan sampel menggunakan teknik purposive sampling yang menggunakan kriteria tertentu berjumlah 24 perusahaan dalam empat periode. Teknik analisis data menggunakan analisis regresi linier berganda. Hasil penelitian ini menunjukkan bahwa green accounting tidak berpengaruh terhadap kinerja keuangan yang diukur menggunakan net profit margin.
\end{abstract}

Kata Kunci: green accounting; aktivitas lingkungan; produk ramah lingkungan; kinerja lingkungan; kinerja keuangan; net profit margin 


\section{PENDAHULUAN}

Era revolusi industri saat ini mengakibatkan sejumlah perusahaan melakukan transformasi teknologi berbasis efisiensi. Hal ini ditandai dengan adanya transformasi teknologi perusahaan yang semakin canggih sehingga mampu meningkatkan kapasitas produksi, menghasilkan berbagai varian produk, menekan biaya produksi, serta menciptakan penawaran produk yang sangat terjangkau untuk memenuhi kebutuhan manusia. Hadirnya teknologi tersebut tentu dimulai dengan adanya investasi secara besar pada bidang reseacrh and development internal perusahaan yang berorientasi pada penekanan biaya pada faktor produksi (Zhao, et. al, 2018). Orientasi tersebut tentunya belum tepat jika hanya didasarkan pada proses produksi. Akibatnya, limbah sisa produksi menjadi salah satu permasalahan lingkungan ketika perusahaan mengabaikan pengelolaan limbah yang dihasilkan. Selama beberapa dekade terakhir, pengelolaan limbah hasil industri telah berkembang sebagai tanggapan dalam menyelesaikan masalah lingkungan. Namun, pengelolaan limbah saat ini masih berfokus pada pengurangan dampak lingkungan daripada pencegahan yang berkelanjutan, seperti melalui multi-media approach dengan memungkinkan terjadinya limbah gas, cair, dan padat, serta penggambaran secara holistik limbah yang dihasilkaan dari proses hulu hingga hilir produksi. (Singh, et. al, 2014).

Berdasarkan data dari Badan Pusat Statistik (BPS) tahun 2018 menunjukkan jumlah pengelolaan limbah berbahaya dan beracun (B3) di Indonesia selama tahun 2015 hingga 2018 cenderung menurun. Tahun 2015 hingga 2017 sektor pertambangan masih menduduki peringkat pertama dalam pengelolaan limbah terbanyak. Peringkat kedua diduduki oleh sektor jasa yang mengelola limbah, dan sektor manufaktur menduduki peringkat ketiga dalam pengelolaan limbah industri yaitu hanya sebesar $1,2 \%$ pada tahun 2017 . Data tersebut menunjukkan bahwa sektor manufaktur mempunyai tingkat kesadaran yang rendah dalam pengelolaan limbah yang berpengaruh terhadap lingkungan. Hal ini karena banyaknya daerah yang sudah memulai memainkan peran dalam kegiatan ekonomi yang artinya daerah-daerah sudah mulai menghasilkan barang dan menyediakan kebutuhan bagi masyarakatnya sendiri. Untuk menghadapi tren peingkatan limbah industri, sudah seharusnya diperlukan strategi manajemen limbah yang berkelanjutan (Mallak, et. al, 2016).

Kementerian Lingkungan Hidup dan Kehutanan (KLHK) telah menghentikan operasional beberapa perusahaan atas keluhan masyarakat karena adanya limbah yang mencemari lingkungan. Beberapa diantaranya yaitu kasus PT Toba Pulp Lestari Tbk, (PT Indorayon) tahun 2003 silam, dan kasus PT SMART Tbk tahun 2010 yang akhirnya menarik PT Unilever Indonesia Tbk ke jalur hukum. Kasus-kasus tersebut tidak sesuai dengan arah pergerakan perusahaan saat ini, yaitu menuju arah pergerakan green company (Kusumaningtias, 2013). Adanya era green company dan penerapan green accounting telah menjadi hal yang menarik bagi masyarakat.

Green accounting merupakan penerapan akuntansi yang memasukkan biaya untuk pelestarian lingkungan (Zulhaimi, 2015). Tujuan dari adanya green accounting sebenarnya untuk mengurangi biaya dampak lingkungan atau sociental cost sehingga perusahaan tidak perlu lagi mengeluarkan biaya tersebut jika telah diantisipasi di awal produksi (Magablih, 2017). Terdapat beberapa macam bentuk aktivitas yang mencerminkan praktik green accounting dalam perusahaan, yaitu: (1) Adanya penggunaan bahan baku yang ramah lingkungan, (2) Adanya manajemen limbah yang tidak menimbulkan polusi ataupun kerusakan lingkungan sekitar, (3) Adanya Corporate Social Responsibility (CSR), yang menjadi bukti perhatian perusahaan akan lingkungan sekitar.

Praktik green accounting tersebut mencerminkan adanya suatu aktivitas lingkungan dalam operasional perusahaan yang mendorong perusahaan untuk meningkatkan kinerja lingkungan (Wireza, 2017). Selain itu, adanya produk ramah lingkungan juga dapat menjadi bukti bahwa perusahaan telah menerapkan green accounting dalam kegiatan operasionalnya. Adanya produk ramah lingkungan tersebut dapat memberikan keuntungan finansial perusahaan di masa yang akan datang, di mana ketika perusahaan mampu untuk membuat produk ramah lingkungan secara tidak langsung perusahaan juga dapat terhindar dari klaim publik dan pemerintah dari perusakan lingkungan. Sebagai contoh pada bidang kehutanan, penerapan green company yang didasarkan pada FMC (Forest Management Certification) di Indonesia juga sedikit berhasil mengubah sentimen publik mengenai perusahaan kehutanan dan mengurangi deforestasi sehingga terciptanya good corporate governance, kepercayaan publik, dan terhindar klaim kerusakan lingkungan oleh pemerintah (Miteva, et. al, 2015).

Pemerintah melakukan evaluasi mengenai keefektifan penerapan manajemen lingkungan yang dilakukan oleh perusahaan. Penerapan Program Penilaian Peringkat Kinerja Perusahaan (PROPER) oleh KLHK digunakan untuk evaluasi pengelolaan lingkungan perusahaan, termasuk pengelolaan limbah. Penerapan PROPER tentunya juga berimplikasi positif pada perlindungan masyarakat adat dan hutan karena perusahaan dituntut memenuhi kewajibannya terhadap kelestarian lingkungan sehingga terhindar dari pencemaran limbah industri (Helmi, et. al, 2020). Faktanya, pada tahun 2018 terjadi penurunan tingkat kepatuhan PROPER yang mengindikasikan peningkatan sikap tidak peduli perusahaan pada aspek kelestarian lingkungan. Penerapan PROPER ini dapat menjadi salah satu indikator masyarakat atas kinerja lingkungan yang dilakukan oleh perusahaan. Beberapa peneliti mengungkapkan bahwa ketidakpatuhan menjalankan 
PROPER akibat dari tidak adanya benefit secara ekonomi ke perusahaan. Pelaksanaan green companies memiliki dampak negatif terhadap pertumbuhan bisnis perusahaan namun berdampak positif terhadap penghematan anggaran belanja pemerintah karena pemerintah tidak perlu mengorbankan anggaran aset kelestarian lingkungan (Lukas, 2015).

Penelitian yang dilakukan oleh Wireza (2017) menunjukkan green accounting menggunakan kinerja lingkungan, produk ramah lingkungan, dan aktivitas lingkungan tidak berpengaruh terhadap net profit margin dan EBITDA margin. Sedangkan menurut Sulistiawati dan Novi (2016) bahwa kinerja lingkungan menggunakan peringkat PROPER berpengaruh parsial positif terhadap profitabilitas dan pengungkapan lingkungan tidak berpengaruh positif terhadap profitabilitas (Profit Magin Sales, Return on Total Assets (ROA), Basic Earning Power (BEP), dan Return on Equity (ROE)).

Penelitian ini menggunakan green accounting yang berfokus pada aktivitas lingkungan perusahaan, penggunaan produk ramah lingkungan, dan kinerja lingkungan perusahaan yang diukur menggunakan peringkat PROPER. Sedangkan kinerja keuangan berfokus pada net profit margin.

\section{METODE}

Penelitian ini termasuk dalam penelitian kuantitatif yang menguji pengaruh green accounting dengan variabel aktivitas lingkungan, produk ramah lingkungan, dan kinerja lingkungan, terhadap kinerja keuangan yang diproksikan net profit margin. Pengukuran variabel tersebut terinci dalam Tabel 1. Terdapat beberapa kriteria dalam penentuan sampel yang menggunakan teknik purposive sampling: (1) Perusahaan mengikuti PROPER periode 2015-2018; (2) Perusahaan menerapkan praktik green accounting yang diterbitkan dalam laporan tahunan dan laporan keberlanjutan; (3) Perusahaan terdaftar di BEI periode 2015-2018; (4) Perusahaan mempunyai data yang lengkap terkait variabel. Hasil sampel terdapat 24 perusahaan yang terinci dalam Tabel 2. Metode dokumentasi dilakukan dengan cara menelusuri laporan tahunan, laporan keberlanjutan, dan laporan tahunan PROPER yang diterbitkan oleh KLHK periode 20152018. Penelitian ini menggunakan pengolahan data analisis regresi linier berganda.

\section{HASIL}

Analisis statistik deskriptif variabel Tabel 3. Uji normalitas one-sample Kolmogorov-Smirnov pada menunjukkan nilai Asymp. Sig. (2-tailed) sebesar 0,151, maka dapat disimpulkan data telah terdistribusi secara normal. Uji Multikolinearitas menunjukkan nilai VIF berturut-turut 1,$383 ; 2,637$; dan 3,115 yang berarti data tidak terjadi multikolinearitas. Uji heterokedastisitas menggunakan uji Glejser bahwa nilai signifikansi ketiga variabel tersebut menunjukkan angka 0,$716 ; 0,687$; dan 0,684 , maka dapat disimpulakan bahwa data penelitian terbebas dari adanya heterokedastisitas.

Uji autokorelasi terlihat nilai Durbin Watson sebesar 1,753 , yang berarti bahwa tidak ada autokorelasi positif maupun negatif. Untuk memperjelas analisis, maka dilakukan uji Runs Test menunjukkan nilai Asymp. Sig. (2-tailed) sebesar 0,747, maka penelitian ini terbebas dari adanya autokorelasi dan telah lolos uji asumsi klasik.

Hasil uji regresi ditunjukkan dengan persamaan berikut (Tabel 4):

$\mathrm{NPM}=0,014+0,004 \mathrm{AL}+0,002 \mathrm{PRL}+0,017 \mathrm{KL} \ldots(1)$

$$
\begin{aligned}
& \text { Keterangan: } \\
& \mathrm{NPM}=\text { Net profit margin } \\
& \beta_{0} \quad=\text { Bilangan konstanta } \\
& \beta_{1}, \beta_{2}, \beta_{3}=\text { Koefisien regresi } \\
& \mathrm{AL} \quad=\text { Aktivitas lingkungan } \\
& \mathrm{PRL} \quad=\text { Produk ramah lingkungan } \\
& \mathrm{KL} \quad=\text { Kinerja lingkungan }
\end{aligned}
$$

Koefisien determinasi menunjukkan nilai sebesar 0,017 (Tabel 5) yang berarti bahwa variabel dependen aktivitas lingkungan, produk ramah lingkungan, dan kinerja lingkungan memberikan pengaruh sebesar 1,7\% terhadap net profit margin. Berdasarkan Tabel 6 dapat diketahui bahwa uji signifikansi simultan mempunyai nilai 0,221 , dapat disimpulkan bahwa variabel aktivitas lingkungan, produk ramah lingkungan, dan kinerja lingkungan secara bersama-sama tidak perpengaruh signifikan terhadap net profit margin. Uji statistik $\mathrm{t}$ menunjukkan bahwa ketiga variabel tidak berpengaruh secara signifikan terhadap net profit margin.

\section{PEMBAHASAN}

Hasil penelitian ini mengungkapkan bahwa pengungkapan aktivitas lingkungan perusahaan manufaktur periode 2015-2018 tidak berpengaruh terhadap kinerja keuangan yang diproksikan dengan net profit margin. Penelitian Farah, Lindrianasari \& Asamaranti (2016) dan Wireza (2017) menjelaskan bahwa terdapat beberapa alasan yang mendasari keputusan perusahaan akan pengungkapan aktivitas lingkungannya.

Pertama, perusahaan lebih cenderung berorientasi pada laba. Perusahaan yang hanya bertujuan pada peningkatan laba akan mempertimbangkan setiap biaya yang dibebankan, termasuk untuk aktivitas lingkungan yang mengurangi besaran bottom line. Adanya tambahan biaya bagi perusahaan tersebut akan menjadi beban yang disebut biaya lingkungan. Hal ini sesuai dengan penelitian Tunggal dan Fachrurrozie (2014) yang menyatakan bahwa saat perusahaan 
melakukan pengelolaan lingkungannya, maka perusahaan akan mengalokasikan biayanya melalui adanya pengungkapan lingkungan atau environmental costs yang dapat menyebabkan berkurangnya laba perusahaan. Hal ini menyebabkan manajemen lebih tertarik untuk fokus pada pengungkapan informasi keuangan daripada pengungkapan aktivitas lingkungan.

Kedua, pengungkapan aktivitas lingkungan dalam laporan tahunan atau laporan keberlanjutan membutuhkan persiapan yang matang, karena pengungkapan tersebut secara tidak langsung akan memberikan pengaruh bagi citra perusahaan atas pengungkapan aktivitas lingkungannya. Masyarakat akan melihat aktivitas perusahaan dalam menjalankan operasionalnya, yang nantinya akan berpengaruh pada legitimasi perusahaan. Penilaian publik dan pengalaman kinerja perusahaan berpengaruh terhadap keputusan membeli sehingga jika konsumen memiliki pengalaman baik maka akan memberitahukannya kepada konsumen lain (Akhtar, et. al, 2017). Ketika perusahaan mempunyai citra yang baik dalam pengelolaan lingkungannya, maka perusahaan akan diterima masyarakat. Sebaliknya, bagi perusahaan yang memiliki keterbatasan aktivitas lingkungan, maka akan cenderung menahan pengungkapannya. Dengan demikian, hanya perusahaan yang mempunyai informasi bersifat positif yang siap mengungkapkan aktivitas lingkungannya (Sulistiawati dan Dirgantari, 2016).

Hasil penelitian ini mengungkapkan bahwa produk ramah lingkungan perusahaan manufaktur periode 2015-2018 tidak berpengaruh terhadap kinerja keuangan yang diproksikan dengan net profit margin. Produk yang dihasilkan perusahaan yang menerapkan pelestarian lingkungan akan cenderung memiliki harga lebih tinggi. Hal tersebut didukung oleh penelitian Nasir dan Saputro (2019) yang menyatakan bahwa tingginya harga produk ramah lingkungan berpengaruh pada permintaan produk, karena adanya pesaing produk sejenis yang menawarkan harga lebih murah. Beberapa negara terdapat aksi nyata dalam upaya melindungi lingkungan justru mendapatkan apresiasi baik terhadap penilaian publik. Walaupun dalam pencatatan akuntansi yang menunjukkan pengungkapannya sangat buruk namun upaya dalam membuat produk yang ramah lingkungan telah dijalankan sehingga mendapat perhatian dari publik (Ahmad, 2012).

Tingginya harga produk ramah lingkungan tersebut disebabkan karena produk yang dibuat oleh perusahaan memuat beberapa aspek tertentu mengenai kualitas produk lebih tahan lama, dalam artian tidak mudah rusak, tidak mengandung racun, dapat didaur ulang, dan packaging yang minimalis. Proses produksi produk ramah lingkungan dalam menghasilkan green product masih membutuhkan sumber daya yang masih menghasilkan emisi tetapi masih memenuhi syarat ramah lingkungan. Akibatnya, produksi untuk peningkatan kualitas bagi produk ramah lingkungan masih membutuhkan biaya tinggi, yang menimbulkan tingginya harga produk ramah lingkungan. Harga produk yang tinggi tersebut tidak sejalan dengan minat beli masyarakat. Utami, et. al, (2014) menyebutkan bahwa masyarakat dengan pengetahuan lingkungan dan kepedulian lingkungan belum tentu mempunyai minat tinggi terhadap produk ramah lingkungan. Hal ini juga diperkuat penelitian dari Lim, et. al, (2013) yang menyebutkan bahwa tingginya harga produk ramah lingkungan dikarenakan banyak faktor seperti: promosi produk yang belum masif, rendahnya konsumen yang berminat produk ramah lingkungan, dan segmentasi produk yang masih berfokus pada demografis dibandingkan psikografis.

Hasil penelitian ini mengungkapkan bahwa penilaian kinerja lingkungan melalui PROPER perusahaan manufaktur periode 2015-2018 tidak berpengaruh terhadap kinerja keuangan yang diproksikan dengan net profit margin. Penelitian ini sejalan dengan penelitian Wiranty dan Kartikasari (2018) serta Rokhmawati, et. al, (2015), yang menyebutkan beberapa alasan yaitu karena publikasi peringkat PROPER masih kurang populer di kalangan masyarakat maupun investor. Bagi investor yang mencari informasi perusahaan, akan langsung menuju website atau media lain, sedangkan informasi mengenai peringkat PROPER sebagai upaya pelestarian lingkungan perusahaan berada dalam ranah Kementerian Lingkungan Hidup dan Kehutanan. Hal ini dapat terjadi karena minimnya pengetahuan masyarakat akan penghargaan pemerintah dari usaha melestarikan lingkungan yang dilakukan. Selain itu, masyarakat lebih mengenal penilaian lingkungan yang lebih dahulu diterapkan, seperti ISO 14001 yang tidak membutuhkan sertifikat PROPER untuk memastikan bahwa produk tersebut aman dan memenuhi standar.

Pelaksanaan green accounting melalui adanya penerapan aktivitas lingkungan, menghasilkan produk ramah lingkungan yang dikonsumsi oleh masyarakat, maupun perolehan peringkat PROPER membutuhkan alokasi biaya lingkungan. Adanya biaya lingkungan dianggap sebagai beban perusahaan karena mengurangi laba. Perusahaan seharusnya menilai bahwa biaya lingkungan adalah pengeluaran investasi, karena dapat memberikan legitimasi sosial dan penilaian ramah lingkungan dari pemerintah dan masyarakat. Pencatatan biaya lingkungan perusahaan juga dapat memberikan citra positif bagi investor yang berdampak pada pengambilan keputusan investasi.

\section{KESIMPULAN}

Green accounting yang diproksikan dengan aktivitas lingkungan, produk ramah lingkungan, dan kinerja lingkungan tidak berpengaruh terhadap kinerja keuangan yang diproksikan dengan net profit margin. Perusahaan yang menerapkan green accounting membutuhkan alokasi khusus biaya lingkungan. 
Adanya biaya tersebut dianggap sebagai beban yang dapat mengurangi laba perusahaan. Biaya lingkungan merupakan investasi masa datang. Penerapan green accounting dapat memberikan legitimasi sosial dan penilaian produk ramah lingkungan perusahaan, sehingga reputasi perusahaan akan meningkat.

\section{DAFTAR PUSTAKA}

Ahmad, A. 2012. Environmental Accounting \& Reporting Practices: Significance and Issues: A Case from Bangladeshi Companies. Global Journal of Management and Business Research, 12(4): 118-127.

Akhtar, S., Xicang, Z., \& Iqbal, S. 2017. Impact of Brand Image on the Profitability of Firm, Analysis of Nestle Compay Pakistan. Review of Public Administration and Management, 5(3): 1-4.

Farah, D., Lindrianasari., \& Asamaranti, Y. 2016. Environmental Management Activity toward Financial Performance in Indonesia Mining Companies. Journal of Environment and Sustainability (IJES).

Fathurahman, M. 2012. Metode Cochrane-Orcutt untuk Mengatasi Autokorelasi pada Regresi Ordinary Least Squares. Jurnal Eksponensial.

Helmi, H., Kusniati, R., Syam, F., Fathni, I. and Hartati, J.N., 2020. Legal Protection to Manage Forest Resources Based on Local Wisdom. Journal of Critical Reviews, 7(9), pp.623-627.

Jannah, R. 2014. Analisis Faktor-Faktor yang Mempengaruhi Carbon Emission Disclosure Pada Perusahaan di Indonesia (Studi Empiris pada Perusahaan yang Terdaftar di Bursa Efek Indonesia Periode 2010-2012.

Kusumaningtias, R. 2013. Green Accounting, Mengapa dan Bagaimana? Proceeding Seminar Nasional Dan Call for Paper Sancall.

Lim, W.M., Ting, D.H., Ng, W.K., Chin, J.H. and Boo, W.X.A., 2013. Why Green Products Remain Unfavorable Despite Being Labelled Environmentally-Friendly?. Contemporary Management Research, 9(1).

Lukas, E. N. 2015. Green Economy for Sustainable Development and Poverty Eradiction. Mediterranean Journal of Social Sciences, 6(6):434-443.

Magablih, A. M. 2017. The Impact of Green Accounting for Reducing the Environmental Cost in Production Companies. Journal of Modern Accounting and Auditing, 13(6): 249-265.

Mallak, S. K., Elfghi, F. M., Rajagopal, P., Vaezzadeh, V., \& Fallah, M. 2016. Overview of Waste Management Performance of Industrial Sectors by Selected Asian Countries: Current Practices and Issues.
International Proceedings of Chemical, Biological, and Environmental Engineering, 99(8): 66-75.

Miteva, D.A., Loucks, C.J., \& Pattanayak S.K. 2015. Social and Environmental Impacts of Forest Management Certifcation in Indonesia. PLoS ONE, 10(7):1-18.

Nasir, M. \& Saputro, E. 2019. Daya Tarik Produk Ramah Lingkungan. Seminar Bisnis Magister Manajemen.

Rokhmawati, A., Sathye, M., \& Sathye, S. 2015. The Effect of GHG Emission, Environmental Performance, and Social Performance on Financial Performance of Listed Manufacturing Firms in Indonesia. Social and Behavioral Sciences.

Sianturi, R. 2014. Faktor yang Menentukan Audit Delay dan Pengaruhnya Terhadap Reaksi Investor. Skripsi. Universitas Bengkulu, Bengkulu.

Singh, J., Laurenti, R., Sinha, R., \& Frostell, B. 2014. Progress and Challenges to the Global Waste Management System. Wasete Management \& Research, 32(9): 800-812.

Sulistiawati, E. \& Dirgantari, N. 2016. Analisis Pengaruh Penerapan Green Accounting Terhadap Profitabilitas Pada Perusahaan Pertambangan yang Terdaftar di Bursa Efek Indonesia. Jurnal Reviu Akuntansi Dan Keuangan Vol. 6 No. 1.

Tjahjono, M. 2013. Pengaruh Kinerja Lingkungan Terhadap Nilai Perusahaan dan Kinerja Keuangan. Jurnal Ekonomi.

Tunggal, W. \& Fachrurrozie, O. 2014. Pengaruh Enviromental Performance, Environmental Cost dan CSR Disclosure Terhadap Financial Performance. Accounting Analysis JournalAAJ.

Utami, D., Gunarsih, T., \& Aryanti, T. 2014. Pengaruh Pengetahuan, Kepedulian dan Sikap pada Lingkungan Terhadap Minat Pembelian Produk Hijau. Media Trend, 9.

Wiranty, D. \& Kartikasari, D. 2018. Pengaruh Kinerja Lingkungan dan Pengungkapan Lingkungan Terhadap Kinerja Keuangan Perusahaan. Simposium Nasional Akuntansi Vokasi VII.

Wireza, S. 2017. Analisis Pengaruh Penerapan Green Accounting Terhadap Profitabilitas Pada Perusahaan Manufaktur Yang Terdaftar di Bursa Efek Indonesia Tahun 2013-2015. Skripsi. Universitas Andalas, Padang.

Zhao, T., Song, Z., \& Li, T. 2018. Effect of Innovation Capacity, Production Capacity and Vertical Specialization on Innovation Performance in China's Electronic Manufacturing: Analysis from the Supply and Demand Sides.

Zulhaimi, H. 2015. Pengaruh Penerapan Green Accounting Terhadap Kinerja Perusahaan (Studi Pada Perusahaan Peraih Penghargaan Industri Hijau Yang Listing Di BEI). Jurnal Riset Akuntansi Dan Keuangan. 
Tabel 1. Operasionalisasi Variabel

\begin{tabular}{|c|c|}
\hline Variabel & Rumus \\
\hline \multicolumn{2}{|c|}{ Green Accounting (X) } \\
\hline $\begin{array}{l}\text { Aktivitas Lingkungan } \\
\text { (Laporan Tahunan dan } \\
\text { Laporan Keberlanjutan) }\end{array}$ & $\begin{array}{l}\text { Dihitung dari jumlah aktivitas } \\
\text { lingkungan perusahaan }\end{array}$ \\
\hline $\begin{array}{l}\text { Produk R a m a h } \\
\text { Lingkungan (Laporan } \\
\text { Tahunan dan Laporan } \\
\text { Keberlanjutan) }\end{array}$ & $\begin{array}{l}\text { Skor 0: Perusahaan tidak menggunakan } \\
\text { produk ramah lingkungan } \\
\text { Skor 1: Perusahaan menggunakan } \\
\text { produk ramah lingkungan }\end{array}$ \\
\hline $\begin{array}{l}\text { Kinerja Lingkungan } \\
\text { (Peringkat PROPER) }\end{array}$ & $\begin{array}{l}\text { (1) Emas }=5 ;(2) \text { Hijau }=4 ; \text { (3) Biru } \\
=3 ;(4) \text { Merah }=2 ;(5) \text { Hitam }=1\end{array}$ \\
\hline \multicolumn{2}{|l|}{ Kinerja Keuangan (Y) } \\
\hline \multirow[t]{2}{*}{$\begin{array}{l}\text { Net Profit Margin } \\
\text { (Laporan Tahunan) }\end{array}$} & $\begin{array}{l}\text { Earning after } \\
\text { interest and tax }\end{array}$ \\
\hline & sales \\
\hline
\end{tabular}

Sumber: data diolah, 2020

Tabel 2. Sampel Penelitian

\begin{tabular}{rlc}
\hline No & \multicolumn{1}{c}{ Nama Perusahaan } & Kode \\
\hline 1 & PT. Semen Indonesia, Tbk & SMGR \\
2 & PT. Holcim Indonesia, Tbk & SMCB \\
3 & PT. Indocement Tunggal Prakarsa, Tbk & INTP \\
4 & PT. Asahimas Flat Glass, Tbk & AMFG \\
5 & PT. Surya Toto Indonesia, Tbk & TOTO \\
6 & PT. Sumi Indo Kabel & IKBI \\
7 & PT. KMI Wire And Cable & KBLI \\
8 & PT. Kabelindo Murni & BSSW \\
9 & PT. Malindo Feedmill, Tbk & MAIN \\
10 & PT. Japfa Comfeed Indonesia, Tbk & JPFA \\
11 & PT. Argo Pantes, Tbk & AGRO \\
12 & PT. Tifico Fiber Indonesia, Tbk & TFCO \\
13 & PT. Indorama Synthetics & INDR \\
14 & PT. Indofood CBP,Tbk & ICBP \\
15 & PT. Indofood Sukses Makmur, Tbk & INDF \\
16 & PT. Multi Bintang Indonesia Tbk & MLBI \\
17 & PT. Delta Djakarta, Tbk & DLTA \\
18 & PT. Mayora, Tbk & MYOR \\
19 & PT. Siantar Top Tbk & STTP \\
20 & PT. Kalbe Farma, Tbk & KLBF \\
21 & PT. Kimia Farma, Tbk & KAEF \\
22 & PT. Phapros Tbk & PEHA \\
23 & PT. Unilever Indonesia, Tbk & UNVR \\
24 & PT. Akasha Wira, Tbk & ADES \\
\hline Sumber data diolah, 2020 &
\end{tabular}

Sumber: data diolah, 2020
Tabel 3. Analisis Statistik Deskriptif

\begin{tabular}{crrrc}
\hline Var & Min & Max & Mean & Std. Deviation \\
\hline AL & $-5,75$ & 6,27 & 1,8045 & 2,50973 \\
PRL &,- 73 & 1,00 &, 2461 &, 32852 \\
KL &,- 19 & 2,08 &, 8513 &, 50326 \\
NPM &,- 20 &, 30 &, 0250 &, 06328 \\
\hline
\end{tabular}

Sumber: data diolah peneliti, 2020

Tabel 4. Uji Regresi Linier Berganda

\begin{tabular}{ccc}
\hline Model & B & Std. Error \\
\hline (Constant) &, 002 &, 014 \\
AL &, 004 &, 003 \\
PRL &, 002 &, 027 \\
KL &, 017 &, 018 \\
\hline
\end{tabular}

Sumber: data diolah peneliti, 2020

Tabel 5. Uji Koefisien Determinasi $\left(\mathrm{R}^{2}\right)$

\begin{tabular}{ccccc}
\hline Model & $\mathrm{R}$ & R Square & $\begin{array}{c}\text { Adjusted R } \\
\text { Square }\end{array}$ & $\begin{array}{c}\text { Std. Error of } \\
\text { the Estimate }\end{array}$ \\
\hline 1 &, $227^{\mathrm{a}}$ &, 051 &, 017 &, 06274 \\
\hline
\end{tabular}

Sumber: data diolah peneliti, 2020

Tabel 6. Uji Signifikansi Simultan

\begin{tabular}{ccl}
\hline Model & F & Sig. \\
\hline Regression & 1,500 &, $221^{\mathrm{b}}$ \\
\hline Sumber: data diolah peneliti, 2020 &
\end{tabular}

Tabel 7. Uji Statistik T

\begin{tabular}{llrc}
\hline & Model & $\mathrm{t}$ & Sig. \\
\hline 1 & (Constant) &, 141 &, 888 \\
& AL & 1,563 &, 122 \\
& PRL &, 081 &, 935 \\
& KL &, 966 &, 337 \\
\hline
\end{tabular}

Sumber: data diolah peneliti, 2020 